\title{
Hypercaloric Diet and Vitamin E Intake
}

\author{
CATALINA RADULESCU ${ }^{1}$, DANIELA MIRICESC ${ }^{1 *}$, ALEXANDRA TOTAN ${ }^{1 *}$, ANDREEA CRISTINA DIDILESCU ${ }^{2}$, \\ IULIA-IOANA STANESCU ${ }^{3}$, RADU RADULESCU ${ }^{1}$, ANA MARIA ALEXANDRA STANESCU ${ }^{4}$, CONSTANTIN STEFANI ${ }^{4,5}$, \\ MARIA GREABU ${ }^{1}$ \\ ${ }^{1}$ University of Medicine and Pharmacy „Carol Davila”, Faculty of Dental Medicine, Department of Biochemistry, 8 Eroii Sanitari Blvd, 050474, \\ Bucharest, Romania \\ ${ }^{2}$ University of Medicine and Pharmacy "Carol Davila”, Faculty of Dental Medicine, Department of Embryology, 8 Eroii Sanitari Blvd, 050474, \\ Bucharest, Romania \\ ${ }^{3}$ University of Medicine and Pharmacy "Carol Davila”, Faculty of Dental Medicine, Department of Physiology, 8 Eroii Sanitari Blvd, 050474, \\ Bucharest, Romania \\ ${ }^{4}$ University of Medicine and Pharmacy "Carol Davila", Faculty of Dental Medicine, Department of Family Medicine, 8 Eroii Sanitari Blvd, \\ 050474, Bucharest, Romania \\ ${ }^{5}$ Carol Davila University Central Emergency Military Hospital, 8 Eroii Sanitari Blvd. 050474, Bucharest, Romania
}

PLGA (poly-lactic-co-glycolic acid) nanoparticles represent an important synthetic biocomponent that has the potential to be a promising carrier of drugs, proteins, nucleic acids, due to its biodegradability and minimal side effects. The aim of our study was to observe the antioxidant effect of vitamin E loaded in PLGA nanoparticles administered over a period of 3 weeks in Wistar rats treated with a hypercaloric diet. Glutathione (GSH) and malondiadehyde (MDA) biomarkers determined from liver lysate were analyzed to evaluate the oxidative stress $(O S)$ induced by the hypercaloric diet. The results of our study revealed a statistically significant increase for GSH and vitamin E in group 2 of Wistar rats receiving hypercaloric diet and a daily dose of vitamin $E$ versus group 1 ( $p<0.005)$. The antioxidant effect of vitamin $E$ was also observed by the statistically significant decrease of MDA in group 2 of Wistar rats compared with group 1. The daily dose of vitamin E has improved the liver redox status of group 2 Wistar rats.

Keywords: hypercaloric diet, antioxidant activity, liver

Nanotechnology works with nanomaterials who have a vast potential as a delivery vehicle for drugs, due to their size, which varies between $1-100 \mathrm{~nm}[1,2]$.

Nanoparticles (NPs) are submicronic colloidal structures and have a number of advantages over conventional drug delivery system, such as site-specific target and controlled drug release, enhanced drug potency and reduced systemic toxicity [3-5]. The oral administration of NP's PLGA is preferable, considering advantages such as easy, pain free administration and wide assimilation of the drug [6].

PLGA is a synthetic, biocompatible copolymer made up of lactic and glycolic acids, which are metabolized in the human body following the Krebs cycle and eliminated as water and carbon dioxide [7, 8]. PLGA has numerous advantages such as: (i) biodegradability, (ii) is approved by the FDA (USA Food and Drug Administration), (iii) has the possibility to target nanoparticles to specific organs or cells, drug protection from degradation, (vi) possibility of sustained release and (vii) the possibility to modify surface properties to provide better interaction with the biological matter [7, 9].

Vitamin $\mathrm{E}$ is a larger term given to all tocopherols, the $\alpha$-tocopherol having the greatest bioactivity. $\alpha$-tocopherol is a highly potent antioxidant vitamin and a good scavenger for reactive oxygen species (ROS) and protects the cell membrane against lipid peroxidation. The hydroxyl group from $\alpha$-tocopherols structure is capable of donating a hydrogen atom and thus, inhibiting propagation of free radicals reactions [10-12].

Vitamin E presents anti-oxidative, anti-inflammatory, anti-obesity, anti-hyperglycemic, anti-hypertensive, and antihypercholesterolemic properties [13, 14].

In the duodenum, vitamin $\mathrm{E}$ is incorporated along with lipid digestion products in micelles which are then absorbed by enterocytes [13-15].

One of the main concerns for the population well-being are the hypercaloric diet and a sedentary life style. Hypercaloric diet leads to obesity, which is a risk factor for cardiovascular diseases, type 2 diabetes, dyslipidemic syndrome and non-alcoholic fatty liver. Non-alcoholic fatty liver disease (NAFLD) is considered the hepatic manifestation of the metabolic syndrome and has a high risk of mortality due to end-stage cirrhosis and hepatocellular carcinoma. NAFLD molecular pathogenesis is not completely elucidated yet. Obesity should be considered an important risk factor for NAFLD [16-19]. 
The liver, the headquarter of important biochemical processes (gluconeogenesis, ureogenesis, oxidative phosphorylation, glycolysis, lipogenesis) is also an important player in the detoxification processes. The development of hepatic steatosis is influenced by a diet rich in saturated fat together with an increased lipogenesis process [20, 21$].$

The hypercaloric diet leads to obesity and metabolic syndrome, characterized by hyperglycemia, chronic inflammation, lipid oxidation, decreased antioxidant levels and systemic OS installation [22-24]. Increased intracellular ROS levels triggers structural and functional alterations in the nucleic acids, proteins and lipids [25].

The most studied biomarker of lipid peroxidation is MDA, generated via peroxidation of arachidonic acid and other polyunsaturated fatty acids [26].

GSH, a tripeptide composed of glutamic acid, cysteine and glycine, is one of the most important intracellular antioxidants. GSH has many relevant biological roles such as: cytotoxic T-cell activation and scavenger for ROS [27, 28].

In our study, PLGA was used as a carrier for vitamin $\mathrm{E}$ to form a protective layer from oxidation and to improve its aqueous solubility, thus enhancing its antioxidant status. The main aim of our study was to observe the antioxidant effects of PLGA-vitamin E at hepatic level.

\section{Experimental part}

Animal model

Our study included 10 Wistar rats that were divided into 2 groups as follows:

-Group 1 represented the control group that received only the hypercaloric diet, consisting mainly of sugar and butter, for a period of three weeks

-Group 2 received the same hypercaloric diet administered to group 1, but associated with a daily dose of PLGAvitamin E

The Wistar rats were obtained from the Animal Facility of Carol Davila University of Medicine and Pharmacy, Bucharest, Romania and the experimental procedures were carried out under Convention 86/609/ E.E.C. from November 24, 1986, for the Protection of Vertebrate Animals Used for Experimental and other Scientific Purposes.

The Wistar rats were kept in polycarbonate cages for three weeks under constant conditions of temperature $\left(22^{\circ} \mathrm{C}\right)$, humidity $(55 \%)$ and light (12 hours dark cycle / light). After three weeks the rats were sacrificed and tissue samples (liver) have been collected. Liver homogenates were obtained using $25 \% \mathrm{KCl}$ solution.

\section{Biomarkers' detection}

PLGA synthesis and the detection of MDA, vitamin E and GSH have already been described in our previous articles $[13,29,30]$.

\section{Statistical analysis}

Statistical analyses were performed using Stata/IC (StataCorp. 2019. Stata Statistical Software: Release 16. College Station, TX: StataCorp LLC).

\section{Results and discussions}

Our experimental results are illustrated in fig. 1, 2 and 3.

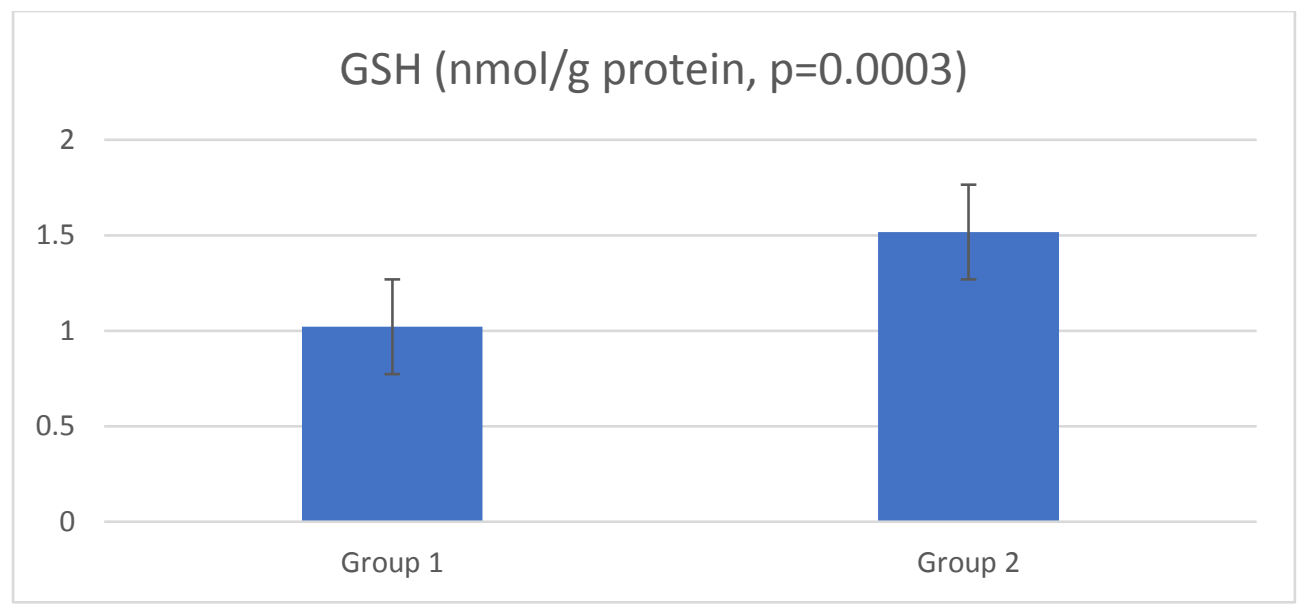

Fig. 1. GSH levels in the hepatic lysate from the 2 groups included in the study 


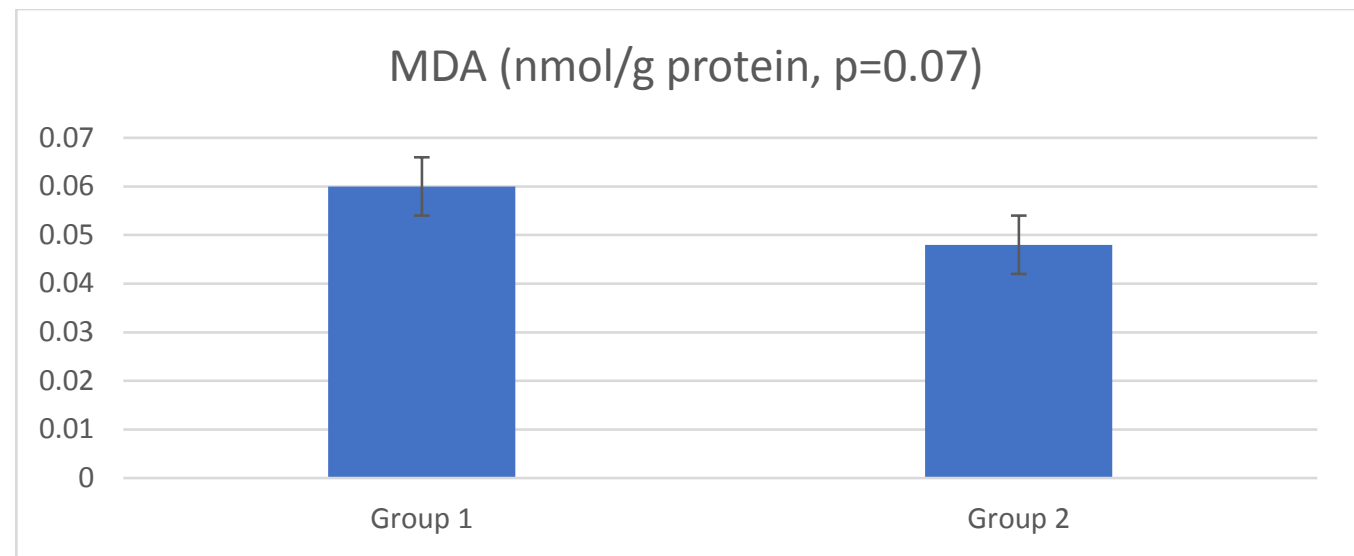

Fig. 2. MDA levels in the hepatic lysate from the 2 groups included in the study

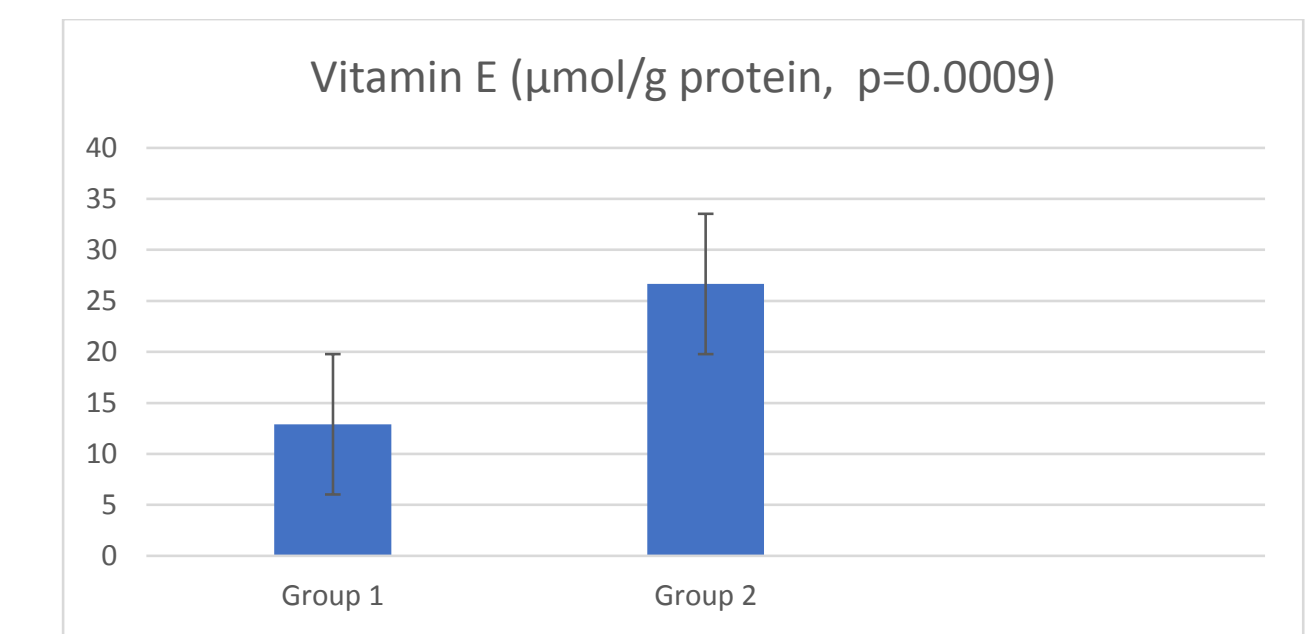

Fig. 3. Vitamin E levels in the hepatic lysate from the 2 groups included in the study Correlations obtained: GSH and MDA, negative correlation: $\mathrm{p}=0.0708$; $\mathrm{r}=--0.7741$; GSH and Vitamin E, positive correlation: $\mathrm{p}=0.0048 ; \mathrm{r}=0.9427$

Previous studies on humans and mice showed that hypercaloric diets such as HFD (high -fat diet) leads to the development of dyslipidemia [31,32]. HFD consumption increases circulating levels of pro-inflammatory cytokines such as NF-kB, IL-6 but also of adipokines [32,33].

Due to the HFD, a large amount of chylomicrons level are synthesized in the intestine and will enter the circulation, generating free fatty acids that will be taken over by the hepatocyte. Hepatocyte free fatty acids will either undergo the mitochondrial beta oxidation process or will suffer an esterification process leading to triglycerides synthesis. A part of the obtained hepatic triglycerides will be stored in the hepatocytes, others will be used for VLDL (very low-density lipoprotein cholesterol) synthesis [34].

The lipid peroxidation process can be produced by three mechanisms: firstly, obesity is characterized by an increase in myocardial oxygen consumption which will lead to the release of a large number of ROS due to the intensification of mitochondrial respiration. The second mechanism refers to the cellular injury that occurs due to the release of cytokines such as TNF- $\alpha$ that generates ROS. The last mechanism proposed is unfortunately the hypercaloric diet that leads to obesity associated with the intensification of oxygen metabolism. Double bonds of fatty acids are vulnerable to oxidation and will lead to lipid peroxidation. MDA is an important biomarker of lipid peroxidation that is increased in obese patients [35]. Patients with NAFLD present elevated serum levels of liver enzymes such as aspartate aminotransferase (AST) and alanine aminotransferase (ALT) [36, 37].

NAFLD is also associated with a systemic inflammatory response, characterized by TNF- $\alpha$, IL-6, IL-1, IL-8, IL-18 and C-reactive protein release [38].

Farelli GC and co-workers confirmed the existence of an association between OS biomarkers such as MDA, TBARS (thiobarbituric acid reactive substances), oxidized VLDL and liver fibrosis. TBARS, MDA, NO (nitric oxide), SOD (superoxide dismutase), CAT (catalase) and vitamin E are potential OS biomarkers proposed for NAFLD assessment [39]. The association between OS and NAFLD was also observed using both laboratory animal studies (Wistar rats) and cell cultures.

Zhang B and co-workers detected in rats fed with HFD increased blood levels of MDA and decreased blood levels of GSH, correlated with hepatic histopathological changes, observed after HE (hematoxylin eosin) staining [40].

The results of our study indicated the existence of a hepatic lipid peroxidation process illustrated by statistically significant increased MDA level in group 1 versus group 2. The hepatic levels of GSH and vitamin E were statistically 
decreased in group 1 versus group 2. Hypercaloric food (sugar and butter) administered daily to Wistar rats led to hepatic OS even after only 3 weeks.

Zhang B and co-workers observed on a BRL-3A cell line that non-esterified fatty acids administration caused a significant decrease of GSH level and a great increase of MDA level [40]. Arya A and co-workers study results revealed increased plasma levels of MDA, ALT and NO metabolites and low levels of plasma SOD [41].

In a cohort study that included 800 obese people, the experimental results, showed elevated levels of ALT, AST and insulin resistance [42].

Totan A and co-workers in a study conducted out on Wistar rats treated with a hypercaloric diet, reported an increased ALT level. After 3 weeks of daily administration of PLGA-vitamin E, ALT level significantly decreased [43].

Omagari K and co-workers in a study conducted over 5-, 9- and 13-weeks used male Sprague-Dawley rats divided in two groups: old and young. The purpose of the study was to find a correlation between NASH (non-alcoholic steatohepatitis) and fat rich in cholesterol. Serum tests including triglycerides, total cholesterol were similar, for both groups.Histopathological analysis found the presence of hepatic steatosis, lobular inflammation and hepatocyte ballooning, revealing the same results as serum tests. The only difference between the two groups, was the liver fibrosis, observed in the old rats group. Expression levels of some inflammatory, OS and cholesterol metabolismrelated genes were also increased in the old rats group, revealing that aging stimulated NASH development [44].

Bertha Araceli Marin-Alejandre and co-workers published in 2019 the results of a study that included ninety-eight individuals with NAFLD, divided into two groups: American Health Association (AHA) and Fatty Liver in Obesity (FLiO). Participants of the study were evaluated at baseline and after six months following a mediterranean diet. After six months of dieting, both groups significantly lost weight and the body mass index and waist circumference were decreased. Systolic blood pressure, diastolic blood pressure, total fat mass and visceral adipose tissue were reduced after six months. The biochemical parameters were also modified after 6 months of diet as follows: total cholesterol level was decreased, HDL was increased and LDL decreased, blood glucose and insulin levels increased, liver inflammation was reduced. Hepatic levels of transaminases and glutamyl-transferase were improved together with the total antioxidant capacity (TAC) [45].

Ivanovski Wajcman D and co-workers divided 789 subjects into two groups according to NAFLD and NASH medical evaluation. After vitamin $\mathrm{E}$ and $\mathrm{C}$ administration, hepatic protective effects were observed [46].

Vitamin $\mathrm{E}$ is currently used as a dietary supplement to improve NAFLD by reducing inflammation and dyslipidemia.

The administration of vitamin E presents a number of limitations because, like the other fat-soluble vitamin and it can be easily oxidized. Chemical and enzymatic instability in gastro-intestinal tract and low mucosal permeability had been observed for vitamin E [47]. Vitamin E encapsulation in PLGA enhances its absorption and protects against gastrointestinal degradation [48].

In order to observe if there is an increased level of vitamin E brought by PLGA nanoparticles in the hepatocytes of group 2 rats, we also performed the vitamin E detection. As expected, group 2 presented a statistically higher level of vitamin E compared to group 1 (figure 3). Between GSH and Vitamin E we also obtained a positive correlation which may suggest that glutathione regeneration also depends on the exogenous contribution of antioxidants.

Our study results showed statistically increased levels of GSH at group 2 of Wistar rats versus group 1. The lipid peroxidation process was also attenuated by decreasing hepatic level of MDA level at group 2 compared with group 1. Statistical analysis of the results indicated a negative correlation between GSH and MDA levels. This correlation illustrates the fact that the lipid peroxidation process increases with the decrease of an important antioxidant such as GSH.

\section{Conclusions}

Obesity induced by hypercaloric diet is involved in the pathogenesis of various systemic disorders such as NAFLD, whose incidence is increasing worldwide. Fat diet induces hepatic OS highlighted by lipid peroxidation process and antioxidants depletion. Liver redox status was improved in Wistar rats who received a daily dose of PLGA-vitamin E. Antioxidant consumption is very important in mediating the harmful effects induced by SO, both in children and adults who adopt a hypercaloric diet. PLGA can be considered a promising carrier of drugs, proteins, nucleic acids and even antioxidants.

\section{References}

1. VIRLAN, M.J., MIRICESCU, D., RADULESCU, R., SABLIOV, C.M., TOTAN, A., CALENIC, B., GREABU, M., Molecules, 21, no. 2, 2016, p.207.

2. YILDIRIMER, L., THANH, N.T.K., LOIZIDOU, M., SEIFALIAN, A.M., Nano Today, 6, no. 6, 2011, p. 585-607.

3. CHEN, X., LIU, L., JIANG, C., Acta Pharm Sin B, 6, no. 4, 2016, p. 261-267.

4. WISSING, S.A., KAYSER, O., MULLER, R.H., Adv Drug Deliv Rev, 56, no. 9, 2004, p. 1257-1272.

5. SHALGUNOV, V., ZAYTSEVA-ZOTOVA, D., ZINTCHENKO, A., LEVADA, T., SHILOV, Y., ANDREYEV, D., DZHUMASHEV, D., METELKIN, E., URUSOVA, A., DEMIN, O., MCDONNELl, K., TROIANO, G., ZALE, S., SAFAROVSMALL A, C.E., J Control Release, 261, 2017, p. 31-42.

6. GHOSH, S., GHOSH, S., SIL, P.C., Toxicol Rep, 6, 2019, p. 358-368.

7. MAKADIA, H.K., SIEGEL, S.J. Polymers (Basel), 3, no. 3, 2011, p. 1377-1397.

8. MARIN, E., BRICENO, M.I., CABALLERO-GEORGE, C., Int J Nanomedicine, 8, 2013, p. 3071-3090.

MATERIALE PLASTICE $\$ 5 \bullet$ no. $4 \diamond 2019$ 940

http://www.revmaterialeplastice.ro
} 
9. DANHIER, F., ANSORENA, E., SILVA, J.M., COCO, R., LE BRETON, A., PREAT, V., J Control Release, 161(2), 2012 , P. 505-22.

10. VARGA, N., TURCSANYI, A., HORNOK, V., CSAPO, E., Pharmaceutics, 11, no. 7, 2019.

11. GIMENEZ-ROTA, C., PALAZZO, I., SCOGNAMIGLIO, M.R., MAINAR, A., REVERCHON, E., DELLA PORTA, G., The Journal Of Supercritical Fluids, 146, 2019, p. 199-207.

12. ESPOSITO, E., SGUIZZATO, M., DRECHSLER, M., MARIANI, P., CARDUCCI, F., NASTRUZZI, C., VALACCHI, G., CORTESI, R., Beilstein J Nanotechnol, 10, 2019, p. 1789-1801.

13. MIRICESCU, D., BALAN, D., RADUlESCU, C., RADUlESCU, R. , STANESCU, I., MOHORA, M., VIRGOLICI, B., TOTAN, A., GREABU, M., Mat. Plast. 56, no.2, 2019, p. 337-340.

14. SHEA, T.B., ORTIZ, D., NICOLOSI, R.J., KUMAR, R., WATTERSON, A.C., J Alzheimers Dis, 7, no. 4, 2005 , p. $297-301$.

15. REBOUL, E., Antioxidants, 6, no. 4, 2017.

16. RICO, D., MARTIN-DIANA, A.B., LASA, A., AGUIRRE, L., MILTON-LASKIBAR, I., DE LUIS, D.A., MIRANDA, J. Nutrients, 11, no.1, 2019.

17. NEUSCHWANDER-TETRI, B.A., Bmc Med, 15, no.1, 2017, p. 45.

18. MIRICESCU, D. TOTAN, A., STANESCU, I., DIDILESCU, A., SFEATCU, R., STANESCU, A.A., STEFANI, C., GREABU M., Mat.Plast., 56, no. 3, 2019, p. 520.

19. RHEE, E.J., Endocrinology and Metabolism, 34, no.3, 2019, p. 226-233.

20. FREITAS, I., BONCOMPAGNI, E., TARANTOLA, E., GRUPPI, C., BERTONE, V., FERRIGNO, A., MILANESI, G., VACCARONE, R., TIRA, M.E., VAIRETTI, M., Oxid Med Cell Longev, 2016.

21. PEREIRA, H.A., DIONIZIO, A.S., FERNANDES, M.S., ARAUJO, T.T., CESTARI, T.M., BUZALAF, C.P., IANO, F.G., BUZALAF, M.A., Plos One, 11, no. 6, 2016, E0158121.

22. RAY, P.D., HUANG, B.W., TSUJI, Y., Cell Signal, 24, no. 5, 2012, p. 981-90.

23. LI, S., XU, M., NIU, Q., XU, S., DING, Y., YAN, Y., GUO, S., LI, F., Plos One, 10, no.10, 2015, E0139455.

24. BARTSCH, H., NAIR, J., Langenbecks Arch Surg, 391, no.5, 2006, p. 499-510.

25. BIRBEN, E., SAHINER, U.M., SACKESEN, C., ERZURUM, S., KALAYCI, O., The World Allergy Organization Journal, 5, no. 1, 2012, p. 9-19.

26. AYALA, A., MUNOZ, M.F., ARGUELLES, S., Oxid Med Cell Longev, 2014, p. 360438.

27. COCO-BASSEY, S.B., ASEMOTA, E.A., OKOROIWU, H.U., ETURA, J.E., EFIONG, E.E., INYANG, I.J., UKO, E.K., Bmc Infect Dis, 19, no.1, 2019, p. 944 .

28. ESPINOZA, S.E., GUO, H., FEDARKO, N., DEZERN, A., FRIED, L.P., XUE, Q.L., LENG, S., BEAMER, B., WALSTON, J.D., J Gerontol A Biol Sci Med Sci, 63, no. 5, 2008, p. 505-509.

29. RADUlESCU, C., MIRICESCU, D., CALENIC, B., RADUlESCU, R., STANESCU, I., CALENIC, A., TOTAN, A.,VIRGOLICI, B., BALAN, D., GREABU, M., Mat. Plast., 55, no. 3, 2018, p. 291-294.

30. MIRICESCU, D., STANESCU, I., PERLEA, P., CALENIC, B., RADULESCU, R., TOTAN, A., VIRGOLICI, B., SABLIOV, C., GREABU, M., Mat. Plast., 54, no. 2, 2017, p. 249.

31. LE LAY, S., SIMARD, G., MARTINEZ, M.C., ANDRIANTSITOHAINA, R., Oxid Med Cell Longev, $2014,908539$.

32. FURUKAWA, S., FUJITA, T., SHIMABUKURO, M., IWAKI, M., YAMADA, Y., NAKAJIMA Y., J Clin Invest, 114, 2004, p.1752-1761.

33. KAUR, J., A., Cardiol Res Pract, 2014, 943162.

34. PESSAYRE, D., BERSON, A., FROMENTY, B., MANSOURI, A., Semin Liver Dis, 21, 2001, p. 57-69.

35. BHALE, D.V., PATIL, D.S., MAHA, R.K., Int J Recent Trends In Sci Technol, 10, 2014, p. 51-52.

36. SCHREINER, A.D., ROCKEY, D.C., Curr. Opin. Gastroenterol, 34, 2018, p. 272-279.

37. SHIRIN, D., PELEG, N., SNEH-ARBIB, O., COHEN-NAFTALY, M., BRAUN, M., SHOCHAT, T., ISSACHAR, A., SHLOMAI, A., Dig. Dis, 37, 2019, p. 69-76.

38. AMIN, R.F., EL BENDARY, A.S., EZZAT, S.E., MOHAMED, W.S., Diabetes Metab. Syndr, 13, 2019, p. $2226-2229$.

39. FARRELL, G.C., HACZEYNI FCHITTURI, S., Adv. Exp. Med. Biol, 1061, 2018, p. 19-44.

40. ZHANG, B., LI, M., ZOU, Y., GUO, H.; ZHANG, B., XIA, C, ZHANG, H, YANG, W, XU, C., Front Cell. Develop. Biol, 7, 2019.

41. ARYA, A., AZARMEHR, N., MANSOURIAN, M., DOUSTIMOTLAGH, A.H., Arch Physil Biochem, 2, 2019, p. 1-8.

42. SUZUKI, A., ANGULO, P., LYMP, J., ST SAUVER, J., MUTO, A., OKADA, T., LINDOR, K., Hepatology, 41, 2005 , p. 64-71.

43. TOTAN, A., BALAN, D.G., MIRICESCU, D., RADULESCU, R., STANESCU, I.I., VIRGOLICI, B., MOHORA, M., GRABU, M., Rev. Chim. (Bucharest), 70, no. 1, 2019, p.78-82.

44. OMAGARI K, ASAKAWA E, SASAO M, NARITA S, HISANO M, FUKUDA A, SURUGA K, ICHIMURA M, TSUNEYAMA K., J Nutr Sci Vitaminol, 65, no. 4, 2019, p. 349-356.

45. MARIN-ALEJANDRE B.A., ABETE, I., CANTERO, I., MONREAL JI., ELORZ, M., HERRERO J.I., BENITO-BOILLOS, A., QUIROGA, J., MARTINEZ-ECHEVERRIA, A., URIZ-OTANO, J.I., PILAR HUARTE-MUNIESA, M., TUR, J.A.,MARTINEZ, ANGELES ZULET, M., Randomized Controlled Trial, Nutrients, 11, 2019, p. 2543.

46. IVANCOVSKY-WAJCMAN, D., FLISS-ISAKOV, N., SALOMONE, F., WEBB, M., SHIBOLET, O., KARIV, R., ZELBER-SAGI, S., Dig Liver Dis, 4, 2019.

47. MURUGESHU, A., ASTETE, C., LEONARDI, C., MORGAN, T., SABLIOV, C. Nanomedicine, 6, no. 9, 2011, p.1513-1528. 48. GRAMA, C.N., ANKOLA, D., KUMAR, M., Curr Opin Colloid In, 16, 2011, p. 238-245.

Manuscript received: 31.10 .2019 